\title{
Malpighi and the Discovery of Capillaries
}

\author{
J.M.S. Pearce \\ Emeritus Consultant Neurologist, Department of Neurology, Hull Royal Infirmary and Hull York Medical School, \\ Hull, UK
}

Key Words

Capillaries $\cdot$ Circulation $\cdot$ Malpighi

\begin{abstract}
Leonardo da Vinci clearly observed and described capillaries. Using the microscope, Marcello Malpighi examined the brain and major organs to demonstrate their finer anatomical features. This led to his discovery in 1661 , of capillaries that proved fundamental to our understanding of the vascular system in the brain and cord. He hypothesized that capillaries were the connection between arteries and veins that allowed blood to flow back to the heart in the circulation of the blood, as first asserted by William Harvey.
\end{abstract}

Copyright $\odot 2007$ S. Karger AG, Basel

Marcello Malpighi (1628-1694) was Professor of anatomy at Bologna, Pisa and Messina. He began to use the microscope, earlier initiated by Robert Hooke in England, Jan Swammerdam in the Netherlands and van Leeuwenhoek of Delft. The microscope enabled him to examine and describe the histology of the lungs, kidneys, spleen and liver. This led to his discovery, in 1661, of capillaries that proved fundamental to our understanding of the vascular system in the brain and cord.

Van Leeuwenhoek [1], unaware of Malpighi's work, rediscovered the blood corpuscles in 1674 and the blood capillaries in late 1683 through the examination of dead

\section{KARGER}

Fax +4161306 1234 E-Mail karger@karger.ch www.karger.com
(C) 2007 S. Karger AG, Basel

0014-3022/07/0584-0253\$23.50/0

Accessible online at:

www.karger.com/ene specimens [2]. In his observation of 1688 however, Van Leeuwenhoek actually saw the blood streaming through the capillaries, and to convince the Royal Society of London, he cited five witnesses to confirm his observations. He considered this one of his most important discoveries.

Much earlier, Leonardo da Vinci, in his dissections (1489-1515), injected the blood vessels with wax for preservation and thereby discovered and named the capillaries, although he did not display their role in linking the arterioles and venules. His biographer, Paolo Giovi, wrote in 1520 :

'In the medical faculty he learned to dissect the cadavers of criminals under inhuman, disgusting conditions ... because he wanted [to examine and] to draw the different deflections and reflections of limbs and their dependence upon the nerves and the joints. This is why he paid attention to the forms of even very small organs, capillaries and hidden parts of the skeleton.'

Malpighi, however, first demonstrated the lymphatic follicles in the spleen and described the renal glomerular capillaries, both of which bear his name. In 1661 (four years after Harvey's death) Malpighi observed for the first time the blood coursing through a network of small tubes on the surface of the lung and in the distended urinary bladder of the frog. He went on to speculate that capillaries were the connection between arteries and veins that allowed blood to flow back to the heart, which completed the chain of the circulation of 
the blood first asserted by William Harvey. His most famed publication was De Viscerum Structura Exercitatio Anatomica. The first edition appeared in 1666, the year of the Great Fire of London, and was followed by a second edition, London, Joseph Martyn, 1669. His discovery of the capillary circulation was published in the form of two letters, 'De Pulmonibus', addressed to Borelli, published at Bologna in 1661 and subsequently reprinted at Leiden and elsewhere. These letters also contained the first account of the vesicular structure of the human lung, and for the first time they made possible a theory of respiration.

He boiled the tissues and then looked for the nerves after boiling had separated them. He showed nerves of the skin entered dermal papillae, which he likened to the horns of a snail, from which account Malpighian corpuscles were named. He pioneered the finer aspects of brain morphology and furnished accurate descriptions of the distribution of grey matter and of the fibre tracts in the cord, with their extensions to the cerebrum and cerebellum; but, reflecting Galenic theory, his microscopy of the grey matter led him to believe that it was a glandular structure that secreted the 'vital spirits'.

His examinations of the chick embryo formed the groundwork for much of modern embryology. Biologists also owe Malpighi a debt for his early studies on the anatomy of the silkworm. He achieved considerable eminence and repute and was appointed Physician to Pope Innocent XII.

In the first section of his book, which relates to the Liver ('Hepate'), Malpighi describes its glandular/secretory nature. In the section related to the cerebral cortex ('Cerebri Cortice'), Malpighi makes the first thorough study of the fine anatomical details of the brain. Although most of his theories of brain function were incorrect, he established the distribution of the grey matter of the brain.

In the section related to the kidney ('Renibus'), Malpighi identified capillaries by injecting coloured water into the renal artery, whereupon he noted 'innumerable ballshaped structures which appeared in the renal tissue hanging like apples ('veluti poma') from the branches of the interlobular arteries. These were long known as 'malpighian corpuscles or bodies' until Schumlansky introduced the term 'glomerulus' in 1788.

When dealing with the spleen ('de liene'), he describes its corpuscles as nodules of lymphatic tissue surrounding the smaller arteries in the spleen. In the blood he showed for the first time that the red colour of blood is due to the presence of small corpuscles (red blood cells).
Nerves, veins and arteries were all grouped together as vessels at that time, and it was believed that the optic nerves were hollow, containing a lumen. However, Andreas Vesalius (1514-1564), contrary to the belief then current, denied this. He declared the nerves to be

\footnotetext{
'... big, rounded structures without any apparent internal cavity, slipping from the skull or dorsal vertebrae and carrying down animal spirit from the brain to produce the animal faculty for the parts of the body ... I scarcely dare to deny the hollowness of the nerve although I have never seen a channel even in the optic nerve; this despite the fact that the nerves, like the veins and arteries, are called vessels and that I am aware that professors of anatomy declare the optic nerves to be hollow.'
}

In man, this idea of a capillary as one of a number of minute blood vessels, in which the arterial circulation ends and the venous begins, first appears in 1667 in the Philosophical Transactions of the Royal Society as: 'The capillary's of the Arteries, and Veins'.

\section{A Brief Note of Malpighi's Final IIIness and Death}

Malpighi eventually died of apoplexy. The clinicopathological description of Wepfer [3] makes fascinating reading. Wepfer had shown that cerebral haemorrhage was the cause of the clinical picture of apoplexy. In Historiae apoplecticorum, published in 1658 [4], is the relevant description: 'The history of the sickness of Marcello Malpighi, the Pope's physician; with an account of the dissection of his corps'.

Wepfer related:

'[On] July 25th 1694 at which Time he was seized in the 66th year of his Age, about 1 a clock in the Afternoon, with an Apoplexy ... attended with a Palsie of the whole right Side, and a distortion of the mouth and Right Eye.... After struggling 40 Days with a long Train of grievous Symptoms, particularly a LightHeadedness, a Capiplenium ${ }^{1}$, and other Accidents, he got clear of the Apoplexy, and Palsie ... He was seiz'd Nov, 29 with a fresh fit of an Apoplexy ... This new fit was usher'd in by a grievous Vertigo, with a fit of a Stone in the Bladder for eight Days ... he dy'd four Hours after the Invasion.'

'When I opened his Head I found in the Cavity of the right Ventricle of the Brain an Extravasation of about 2 pints of black clotted Blood, which was the cause of his Apoplexy and Death.'

\footnotetext{
1 This word is not to be found in the Oxford English Dictinonary; I presume it is derived from Latin caput (head) and plenium (a fullness), hence full-headedness.
} 
References

Malpighi and the Discovery of Capillaries
1 Van Leeuwenhoek A: Microscopical observations concerning blood, milk, bones, the brain, spittle, and cuticula. Philos Trans 1674;9:121-128.

$\checkmark 2$ Lux DS, Cook HJ: Closed circles or open networks? Communicating at a distance during the scientific revolution. Hist Sci 1998;36: 179-211. $\checkmark 3$ Pearce JMS: Johann Jakob Wepfer (16201695) and cerebral haemorrhage. J Neurol Neurosurg Psychiatry 1997;62:387.

4 Wepfer JJ: Historiae apoplecticorum, 1658, Engl transl from Bagvili's Practice of Physik, London, 1704, cited in Major RH: Classic Descriptions of Disease, ed 3, Illinois, Thomas, 1945, pp 474-477. 